\title{
Chromatin Assembly Factor I
}

National Cancer Institute

\section{Source}

National Cancer Institute. Chromatin Assembly Factor I. NCI Thesaurus. Code C111912.

A heterotrimeric protein complex that mediates chromatin assembly by promoting histone $\mathrm{H} 3$ and $\mathrm{H} 4$ deposition onto newly synthesized DNA during replication or DNA repair. This complex is comprised of chromatin assembly factor 1 subunit $A$, chromatin assembly factor 1 subunit B and histone-binding protein RBBP4. 